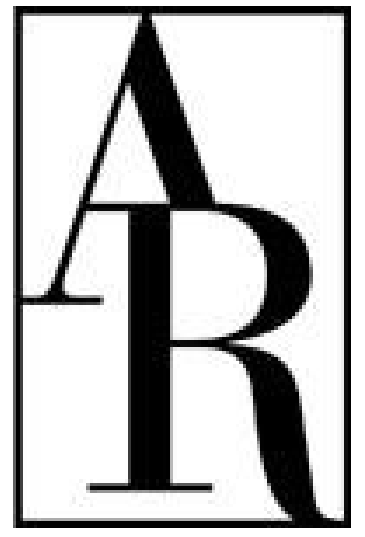

Plant-Vertebrate Seed Dispersal Systems in the Mediterranean: Ecological, Evolutionary, and Historical Determinants

Author(s): Carlos M. Herrera

Reviewed work(s):

Source: Annual Review of Ecology and Systematics, Vol. 26 (1995), pp. 705-727

Published by: Annual Reviews

Stable URL: http://www.jstor.org/stable/2097225

Accessed: $10 / 11 / 201105: 03$

Your use of the JSTOR archive indicates your acceptance of the Terms \& Conditions of Use, available at http://www.jstor.org/page/info/about/policies/terms.jsp

JSTOR is a not-for-profit service that helps scholars, researchers, and students discover, use, and build upon a wide range of content in a trusted digital archive. We use information technology and tools to increase productivity and facilitate new forms of scholarship. For more information about JSTOR, please contact support@ jstor.org. 


\section{PLANT-VERTEBRATE SEED DISPERSAL SYSTEMS IN THE MEDITERRANEAN: Ecological, Evolutionary, and Historical Determinants}

\section{Carlos M. Herrera}

Estación Biológica de Doñana, Consejo Superior de Investigaciones Científicas, Apartado 1056, E-41080 Sevilla, Spain

KEY WORDS: coevolution, frugivorous birds, mutualism, seed dispersal

\section{ABSTRACT}

Investigations on vertebrate seed dispersal systems in the Mediterranean show that extremely efficient plant-disperser mutualisms do not require, and thus are not evidence for, mutual evolutionary adjustments of participants. Current Mediterranean dispersal systems have apparently been shaped by means of 1 . trophic and behavioral adaptations of birds morphologically preadapted to pre-existing plant resources, and 2. disperser-mediated processes of habitatshaping occurring at an ecological time scale. These processes depend on differential recruitment of plant species as a function of disperser preferences, rather than on adjustments based on evolutionary processes. On the plant side, there is a prevalence of historical and phylogenetic effects, which reflects a series of ecological limitations inherent to the interactions between plants and dispersal agents that constrain plant adaptation to dispersers. To test adaptive hypotheses and explanations, future investigations on Mediterranean plant-disperser systems should concentrate more on the animal than on the plant side of the interaction.

\section{INTRODUCTION}

By acting as seed vectors, frugivorous animals play an essential role in the reproductive cycle of their food plants. This circumstance, and the mutualistic 
nature of the relationship, have given rise to considerable interest in the evolutionary consequences of frugivory and seed dispersal for plants and animals $(44,46)$. Although botanists have long been interested in the natural history of seed dispersal by animals $(141,169)$, evolutionary ecologists turned their attention to the subject rather recently, following seminal contributions by Snow $(149,150)$, McKey $(125)$, and Howe \& Estabrook (92). The current interest in plant-disperser mutualisms contrasts with an older research tradition that studied aspects of plant reproduction such as pollination, sex expression, and breeding system, which has been part of mainstream evolutionary biology since its Darwinian inception $(24,25)$.

Interest in plant-disperser systems, and most earlier evolutionary interpretations, was motivated by investigations conducted in tropical forests, habitats that have continued to contribute decisively to our knowledge in this field (44, 46). Away from the tropics, most studies on plant-disperser mutualisms have been in American temperate habitats and in the Mediterranean Basin. This review focuses on the latter region (see 171, 172 for partial reviews of frugivory and seed dispersal by vertebrates in temperate America). Two major reasons justify restricting the geographical scope to the Mediterranean region. On formal grounds, studies on the evolutionary ecology of plant-disperser interactions in the Mediterranean, although numerous, have been not reviewed previously. One further, conceptual reason is that in no other large and ecologically well-defined geographic area have most facets of plant-disperser interactions been so thoroughly investigated as to provide a comprehensive picture of the relative importance of ecological, evolutionary, and historical factors in shaping plant-disperser systems. Studies in the Mediterranean have revealed that current plant-disperser interactions not only may be shaped by adaptive evolution of participants, but may also reflect important limitations imposed by regional history and the phylogeny of the taxa involved $(73,74,82,83)$.

\section{The Mediterranean Environment}

In this review I adhere to the delineation of the Mediterranean region adopted by di Castri (42). The Mediterranean climate is a transitional regime between temperate and dry tropical climates, characterized by a concentration of rainfall in winter, occurrence of a distinct summer drought of variable length, warmto-hot summers, and cool-to-cold winters (42). These climatic characteristics, together with the original features of the plants populating the present-day Mediterranean region, are key elements to understanding the peculiarities of Mediterranean ecosystems. The Mediterranean climate is very young in geological terms. It first appeared in the Pliocene, approximately 3.2 million years ago (155) and, as discussed below, most of the fleshy-fruited plant taxa living at present in the Mediterranean existed prior to the appearance of this climatic type. 
Due to a long history of human-induced perturbations, original Mediterranean habitats either were extirpated long ago or, in the relatively few places where they still persist, have almost invariably been subject to some degree of disturbance $(158,161)$. Plant-disperser interactions are seriously distorted in heavily disturbed Mediterranean habitats $(38,81,139,143)$, hence investigations conducted on extensively human-modified habitats are only rarely considered in this review.

\section{THE PARTICIPANTS}

\section{Vertebrate-Dispersed Plants}

In European temperate forests, fleshy-fruited plants are most abundant in clearings and forest edges but become scarce in the interior of mature forests, which are dominated by nut- or cone-producing trees (136). In lowland and mid-elevation Mediterranean habitats, in contrast, fruit-bearing plants generally replace earlier successional species that are not vertebrate-dispersed (e.g. Cistaceae, Labiatae, Leguminosae; 88, 89), and such plants may eventually dominate the vegetation in undisturbed or lightly disturbed woodlands and shrublands $(54,86,90)$. Vertebrate-dispersed species account for $32-64 \%$ of local woody species richness and $20-95 \%$ of woody plant cover in Mediterranean habitats $(64,86,104,114)$. Their importance is greatest in lowland vegetation on fertile soils, and it declines with elevation, increasing aridity, decreasing soil fertility, and severity of habitat disturbances such as nitrification and fire $(6,54,64,66,86,88,89)$. Mediterranean shrublands and woodlands are intermediate between tropical and temperate forests in fruit production (70). Annual fruit production for some southern Spanish habitats ranges between 60 and $1,400 \times 10^{3}$ ripe fruits/ha, representing $6-100 \mathrm{~kg}$ dry mass/ha (114).

In contrast to temperate habitats, where most fleshy fruit-producing species belong to relatively few plant families (mostly Rosaceae and Caprifoliaceae in Europe and America; 136, 171), local assemblages of vertebrate-dispersed plants in the Mediterranean are taxonomically diverse at the familial level, particularly in the warmer lowlands. This is largely due to the widespread occurrence of several families with current distributions centered on tropical and subtropical regions and northernmost distributional limits in the Mediterranean (e.g. Anacardiaceae, Oleaceae, Santalaceae, Myrtaceae, Lauraceae, Palmae). Most of these families are locally represented by only 1-2 species in single genera (e.g. Pistacia in Anacardiaceae, Olea in Oleaceae, Osyris in Santalaceae, Chamaerops in Palmae; 28, 64, 96, 104). However, as shown later, some play a prominent role in the maintenance of Mediterranean plantdisperser systems owing to their abundance and the nutritional characteristics of their fruits. 


\section{Nonavian Dispersers}

Ants may act as secondary dispersers of the seeds of some fleshy-fruited Mediterranean plants (5), but further studies are needed to assess the generality of the phenomenon. The role of reptiles as dispersal agents has been not studied in detail, but it seems quantitatively unimportant except in some insular situations $(167,168)$. Several species of mammals belonging to the order Carnivora are seasonally frugivorous and disperse the seeds of many plants in undisturbed or lightly disturbed habitats $(18,37,81,135)$. In a southeastern Spanish region, three species of carnivores disperse seeds of 27 species, representing $40 \%$ of the regional fleshy-fruited flora (81). Other mammalian groups such as ungulates (52), rabbits (128), and hedgehogs (56) also sporadically ingest fleshy fruits and disperse seeds, but their importance as dispersers is probably local. The same applies to the Brown Bear (Ursus arctos) and the Barbary Macaque (Macaca sylvanus), which feed on fleshy fruits and disperse the seeds of many plants, in the few regions where they still survive $(81,126$, 127).

The vast majority of Mediterranean fleshy-fruited plants are dispersed either by birds alone or by some combination of birds and carnivorous mammals (37, 81). Indirect evidence based on concurrent studies of the frugivorous diet of birds and mammals in the same region $(64,81,130)$ indicates that birds are the main dispersers of most plants with mixed dispersal. As a group, therefore, birds are by far the most important vertebrate seed dispersers in the Mediterranean, and I focus on bird-plant relationships for the rest of this review.

\section{Avian Dispersers}

Birds of many species eat fleshy fruits in Mediterranean shrublands and woodlands. Not all of these, however, are legitimate seed dispersers, as some feed only on pulp or seeds without effecting dispersal. These "fruit predators" (65) typically are small- and medium-sized finches (Fringillidae) and titmice (Paridae) $(55,64,65,85,112,116,163)$. The distinction between fruit predators and legitimate dispersers, however, is somewhat context-dependent. Fruit predators may sometimes act as dispersers when feeding on small-seeded fruits (e.g. titmice feeding on blackberries; 48, 103), and dispersers may act as predators when feeding on large-seeded fruits (e.g. warblers feeding on olive fruits; 138).

Most legitimate avian dispersers are small- to medium-sized (body mass range $=10-110 \mathrm{~g}$ ) passerines in the families Turdidae (thrushes), Sylviidae (old World warblers), and Muscicapidae (old World flycatchers). In all Mediterranean habitats so far studied, the most important seed dispersers are some combination of species in the genera Sylvia, Turdus, and Erithacus $(39,50$, $64,85,96,103,104,116,165)$. Species in these genera are strong seasonal 
frugivores that feed on many fruit species (Sylvia: 30, 96, 108, 109, 118; Turdus: 32, 33, 53, 60, 115, 131, 151, 173; Erithacus: 19, 34, 58, 111). In four southern Spanish localities, Sylvia atricapilla consumed the fruits of 29 plant species in the period October-March (118). Erithacus rubecula fed on 21 fruit species in southern France (34), and thrushes consume locally the fruits of 5-18 species $(32,53,64,131)$. Species of Sturnidae (47) and Corvidae (116, $152,150 \mathrm{a}$ ) often feed on fleshy fruits but do not seem to be important frugivores anywhere except in the Canary Islands, where Corvus corax is a major disperser for at least 16 plant species (129). Bulbuls (Pycnonotidae) are important dispersers in the Middle East $(3,96,98,99)$ and, most likely, in northern Africa as well (21).

With only minor exceptions (e.g. Sylvia melanocephala, Pycnonotus spp.), Mediterranean avian dispersers are medium- and long-distance migrants that breed in central and northern Europe $(21,22)$. Some species overwinter in tropical and subtropical Africa, appearing in Mediterranean habitats only during spring and autumn migrations. As a rule, these trans-Saharan migrants eat fleshy fruits only in autumn passage (96), but some species are also frugivorous in spring if ripe fruits are available (78). Other species of dispersers overwinter in the Mediterranean Basin from October-March, when they feed almost entirely on fleshy fruits (see below). For most of these species, the Mediterranean Basin is the major or exclusive wintering area in the western Palaearctic (21, 22 ; see 124, 156, for reviews of bird migration in the Mediterranean). Due to their abundance, extended permanence in the region, and extensive frugivory, overwintering species are the most important and genuine avian dispersers of Mediterranean plants.

\section{CONSEQUENCES OF PLANT-BIRD INTERACTIONS}

\section{The Plant Side}

The efficiency of the relationship of the fleshy-fruited plants with dispersal agents may be assessed by considering the success of fruit removal by legitimate dispersers and the patterns of postdispersal seed deposition. On these grounds, the interaction with Mediterranean frugivorous birds is remarkably efficient for most species, particularly in lowland habitats.

Predispersal seed predation by invertebrates on fleshy-fruited Mediterranean taxa is lower, on average, than among coexisting dry-fruited species (88) or on European temperate fleshy-fruited species (67). Except in some montane $(132,163,164,165)$ or disturbed $(121)$ habitats, fruit losses to herbivores and fruit predators are negligible for most species $(68,88,107,110,112)$. Crops of ripe fruits are thoroughly depleted by legitimate frugivores, particularly in the lowlands (Table 1). On average, species in well-preserved lowland habitats 
Table 1 Proportion of ripe fruit crops of Mediterranean fleshy-fruited plants removed by legitimate avian seed dispersers. Species are arranged in decreasing order of fruit removal rate.

\begin{tabular}{|c|c|c|}
\hline Species & $\begin{array}{l}\text { Ripe fruits removed } \\
(\%)\end{array}$ & References \\
\hline Asparagus aphyllus & 100,100 & 1,96 \\
\hline Pistacia lentiscus & $100,99,99,91$ & $64,96,110$ \\
\hline Smilax aspera & $100,91,86$ & $64,96,104$ \\
\hline Phillyrea angustifolia & $99,96^{\mathrm{b}}, 93,83,72^{\mathrm{b}}$ & $64,104,162$ \\
\hline Rhamnus lycioides & $98,98,97$ & 64,104 \\
\hline Osyris alba & 98,76 & 104 \\
\hline Daphne gnidium & 97,92 & 104 \\
\hline Myrtus communis & $95,95,89$ & 64,104 \\
\hline Osyris quadripartita & 94 & 64 \\
\hline Olea europaea & $94,52^{d}$ & 107 \\
\hline Rhamnus alaternus & $93,61^{\mathrm{b}}$ & 64,130 \\
\hline Rubus ulmifolius & $90,92,88,80,86^{b}, 43^{c}$ & $103,104,130$ \\
\hline Lonicera periclymenum & 86,61 & 104 \\
\hline Lonicera etrusca & 84 & 96 \\
\hline Rhamnus palaestinus & 84 & 96 \\
\hline Rubia tenuifolia & 82 & 96 \\
\hline Phillyrea latifolia & $78^{\mathrm{b}, \mathrm{d}}, 32^{\mathrm{b}, \mathrm{d}}$ & 85 \\
\hline Viburnum tinus & $75,51^{\mathrm{b}}$ & 157, CM Herrera, unpubl. \\
\hline Berberis hispanica & $71^{b}, 52^{b}$ & 130,132 \\
\hline Prunus mahaleb & $68^{\mathrm{b}}, 61^{\mathrm{b}}, 53^{\mathrm{b}}, 50^{\mathrm{b}}$ & 116 \\
\hline Osyris alba & 68 & 96 \\
\hline Cornus sanguinea & $49^{c}, 36^{c}, 36^{c}$ & 121 \\
\hline Pistacia terebinthus & $28^{b}$ & 166 \\
\hline
\end{tabular}

\footnotetext{
${ }^{a}$ Mean values of fruit removal rates obtained for individual plants. Different entries for the same species correspond to different localities or years.

${ }^{b}$ Highland habitat $(\geq 1000 \mathrm{~m}$ elevation). Entries without this superscript are from lowland habitats.

${ }^{\mathrm{c}}$ Disturbed habitat.

${ }^{\mathrm{d}}$ Estimated during a season of unusually large fruit crop.
}

have $90.2 \pm 9.4(\mathrm{SD}) \%$ of their ripe fruits consumed by legitimate avian dispersers, which is significantly greater $(P \ll 0.001$, Kruskal-Wallis ANOVA) than the $62.1 \pm 17.7 \%$ exhibited by highland species. Fruit removal success declines in disturbed habitats or when disperser populations become satiated during seasons with unusually large fruit crops (Table 1$)(85,107$, 143).

Depending on the combination of plant and disperser species, seed ingestion by Mediterranean frugivorous birds may enhance germination or not, but there is no documented instance either of detrimental effects of bird ingestion on seed germination or of seeds that obligately require bird ingestion to germinate 
$(9,10,27,98)$. The consequences of seed dispersal by birds for seed survival, seedling ecology, and population recruitment of Mediterranean fleshy-fruited plants are still little known. The limited evidence available suggests that the demographic implications of dispersal are very site- and species-specific (69, $85,99,119,144)$, so few generalizations can be drawn. Different species of frugivores tend to generate characteristic seed shadows, depending on foraging behavior, seed retention times, patterns of fruit selection, and response to the structure of the vegetation $(84,99,105,144)$. The postdispersal seed deposition pattern of a given plant species will therefore depend on detailed aspects of habitat structure and composition of the disperser assemblage.

At the between-habitat scale, bird-dispersed species have a distinct advantage over dry-fruited ones in the colonization of newly available habitat patches $(29,40)$. Seed dissemination, however, is essentially a within-habitat process, as most dispersed seeds travel relatively short distances from the mother plant $(35,41,85)$. In Phillyrea latifolia, postdispersal seed predation was not greater under conspecifics, but recruitment was much reduced there. Seed dissemination from mother plants, although rather restricted spatially, was clearly advantageous in this species (85). Within habitats, no evidence exists for birds preferentially dispersing seeds to particularly favorable germination or survival microsites, and evidence exists of conflicts in the quality of microsites for seeds and seedlings $(69,85,119)$.

Avian frugivores generally feed simultaneously on fruits of several species, and fruiting plants act as focal points for frugivores' foraging, leading to a predictable concentration of dispersed seeds beneath fleshy fruit-producing species or, in the case of dioecious taxa, under fruit-bearing females $(35,41$, $69,85,99$ ). This effect may influence the distribution of fruiting plants in the habitat ("habitat shaping"; 70). The hemiparasitic shrub Osyris quadripartita mostly parasitizes species that, like itself, are bird-dispersed, in proportions correlated with the frequency of co-occurrence of their seeds in the meals of its main disperser $(79,80)$. By producing multispecific seed shadows, dispersers may also influence the absolute and relative abundances of their food plants in local plant communities. The recruitment of seedlings of $P$. latifolia in certain microhabitats is limited by seed rain $(85,119)$, and local percent cover of individual fleshy-fruited species is, at least in some plant communities, directly correlated with their area-specific intensity of fruit production (64).

\section{The Bird Side}

Regardless of whether they are transient fall migrant or overwintering species, major avian dispersers are all extensively frugivorous while inhabiting Mediterranean habitats (Table 2; also 30, 32-34, 45, 159). On average, fruits usually contribute $>75 \%$, and often $>90 \%$, of the food for these species.

Contrary to earlier suggestions (12), recent laboratory studies have shown 
Table 2 Contribution of fleshy fruits to the diet of major Mediterranean avian seed dispersers. Different entries for the same species correspond to different localities. Average values are shown for localities with data for different years.

\begin{tabular}{|c|c|c|c|}
\hline Species and overall mean ${ }^{a}$ & $\begin{array}{l}\text { Mean } \% \text { fruit } \\
\text { volume }\end{array}$ & Period $^{c}$ & References \\
\hline Sylvia atricapilla & 98.3 & FM & 102 \\
\hline \multirow[t]{8}{*}{86.4} & 93.3 & $\mathrm{FM}+\mathrm{OW}$ & 64 \\
\hline & 93.0 & $\mathrm{FM}+\mathrm{OW}$ & 64, CM Herrera unpubl. \\
\hline & 92.4 & $\mathrm{FM}+\mathrm{OW}$ & CM Herrera unpubl. \\
\hline & 86.1 & $\mathrm{FM}+\mathrm{OW}$ & 108 \\
\hline & 82.5 & $\mathrm{FM}+\mathrm{OW}$ & 51 \\
\hline & 79.0 & FM & 50 \\
\hline & 76.3 & OW & 138 \\
\hline & 60.2 & FM & 118 \\
\hline Sylvia borin & 94.7 & FM & 102 \\
\hline \multirow[t]{4}{*}{90.3} & 92.4 & FM & 108 \\
\hline & 91.1 & FM & 64 \\
\hline & 84.1 & FM & 51 \\
\hline & 84.0 & FM & 50 \\
\hline Sylvia communis & 95.8 & FM & 102 \\
\hline \multirow[t]{3}{*}{74.1} & 76.8 & FM & 64 \\
\hline & 70.9 & FM & 108 \\
\hline & 54.2 & FM & 51 \\
\hline Sylvia melanocephala & 83.5 & $\mathrm{R}$ & 64, CM Herrera unpubl. \\
\hline \multirow[t]{3}{*}{70.6} & 73.9 & $\mathbf{R}$ & 108 \\
\hline & 66.6 & $\mathrm{R}$ & 64 \\
\hline & 59.6 & OW & 138 \\
\hline Turdus iliacus & 100.0 & OW & CM Herrera unpubl. \\
\hline \multirow[t]{2}{*}{86.8} & 98.0 & OW & 85 \\
\hline & $85.7^{\mathrm{b}}$ & OW & 151 \\
\hline Turdus merula & 89.6 & OW & 64, CM Herrera unpubl. \\
\hline \multirow[t]{7}{*}{80.1} & 88.2 & $\mathrm{FM}+\mathrm{OW}$ & CM Herrera unpubl. \\
\hline & 88.1 & FM & 102 \\
\hline & $83.0^{\mathrm{b}}$ & $\mathrm{FM}+\mathrm{OW}$ & 153 \\
\hline & 79.4 & $\mathrm{R}+\mathrm{OW}$ & 130 \\
\hline & 75.0 & OW & 50 \\
\hline & 72.8 & $\mathrm{FM}+\mathrm{OW}$ & P Jordano unpubl. \\
\hline & 67.3 & $\mathrm{FM}+\mathrm{OW}$ & 64 \\
\hline Turdus philomelos & 97.2 & OW & P Jordano unpubl. \\
\hline \multirow[t]{3}{*}{91.6} & 92.9 & OW & CM Hedrrera unpubl. \\
\hline & 91.0 & OW & 50 \\
\hline & 78.6 & OW & 138 \\
\hline Turdus torquatus & 96.2 & OW & 173 \\
\hline Turdus viscivorus & 92.8 & $\mathrm{R}$ & 131 \\
\hline Erithacus rubecula & 81.2 & $\mathrm{FM}+\mathrm{OW}$ & CM Herrera unpubl. \\
\hline \multirow[t]{6}{*}{64.8} & 70.2 & OW & $58,64, \mathrm{CM}$ Herrera unpubl. \\
\hline & 69.0 & $\mathrm{FM}+\mathrm{OW}$ & P Jordano unpubl. \\
\hline & 60.5 & OW & 64 \\
\hline & 46.9 & OW & 138 \\
\hline & 43.0 & $\mathrm{FM}+\mathrm{OW}$ & 50 \\
\hline & 45.1 & FM & 102 \\
\hline
\end{tabular}

${ }^{\text {a }}$ Computed using sample sizes as weighting factors.

${ }^{b}$ Based on analyses of stomach contents. Figures without this superscript are based on analyses of fecal and/or gastrointestinal samples.

' FM, fall migration (August-September); OW, overwintering period (October-March); R, year-round resident species, data for the autumn-winter period. 
that extensive consumption of fruits by trans-Saharan migrants at Mediterranean stopover sites may play an important role in migratory fat deposition (7, 148), and field evidence confirms this. Migrating garden warblers (Sylvia borin) feeding on fruits are significantly heavier than conspecifics feeding on insects alone $(109,159)$. As premigratory fat deposition is an essential requisite for successful migration across the Saharan Desert $(8,16)$, extensive frugivory at Mediterranean stopover localities has obvious short-term survival value for fall migrants.

Overwintering frugivores accumulate only small-to-moderate amounts of fat during their October-March stay in Mediterranean habitats, but frugivory is also important for survival. In Sylvia atricapilla and Erithacus rubecula, body mass increases significantly over daytime due to fat storage, which is depleted during the long winter nights $(23,93)$. Lipid-rich fruits (Pistacia, Olea, Viburnum, see below) invariably predominate in the diets of overwintering frugivores (Refs. in Table 2), and they must play an essential role in the daily rebuilding of fat stores. In overwintering $S$. atricapilla, fat accumulation is directly related to the extent of frugivory (109), and fatty acid composition of accumulated fat coincides closely with that of lipids extracted from the fruits that predominate in its diet (63). In the less heavily frugivorous Erithacus rubecula (Table 2), a direct relationship between body mass and fruit consumption has been found among birds overwintering in southern France (34), but not in southern Spain (111).

\section{FACTORS SHAPING THE INTERACTION}

As shown above, the interaction between fleshy-fruited plants and major avian dispersers in the Mediterranean is remarkably efficient for most plants and highly beneficial for the birds. The main proximate and ultimate factors contributing to give rise to these patterns are examined in this section.

\section{Plant Traits}

FRUITING PHENOLOGY Production of fleshy fruits in Mediterranean habitats is seasonal. In the highlands, most species fruit in summer and early autumn, while in lowland and mid-elevation habitats, fruiting peaks during autumn or early winter $(28,39,64,87,96,109,130)$. The shrub Osyris quadripartita (Santalaceae) ripens fruits throughout the year in southwestern Spanish lowlands, but even in this rather atypical species, most individuals ripen most fruits in autumn-winter $(71,78)$. A close match generally exists locally between the seasonal curves of avian disperser abundance and fleshy fruit production or availability $(39,64,96,106)$. Frugivorous birds form an important part of autumn-winter bird communities in lowland and mid-elevation habitats, con- 
stituting $25-50 \%$ of all birds $(39,64,106)$. From summer to winter, the density of frugivores increases locally 6-to 15 -fold, as a consequence of the abundant influx of overwintering species (124).

Bird-fruit phenological matching may reflect adaptive tuning of the ripening season of individual plant species to the time of greatest disperser availability $(150,160)$. Fuentes (49) critically examined this hypothesis for a latitudinal gradient in western Europe including temperate and Mediterranean habitats. At the plant community level, seasonal variation in the total number and biomass of fruits matched variation in abundance of avian frugivores, yet individual species showed no evidence of phenological adjustment to variations in the seasonal pattern of disperser abundance. Fuentes concluded that fruiting patterns at the community level match disperser abundance not because of adaptations by component species, but because of the greater relative abundance (and hence greater contribution to total fruit production) in each locality of those species that fruit when birds are most abundant. These species may have achieved a demographic advantage by getting more seeds dispersed than do species that ripen in other seasons. Debussche \& Isenmann (39) similarly concluded that latitudinal shifts in ripening season occurring in western European plant communities mainly reflect climatic constraints on plants rather than selective pressures from dispersers. In the autumn-fruiting Olea europea and Arbutus unedo, adequate amounts of autumn rainfall are necessary for successful fruit ripening $(20,107)$. Cambial activity in $A$. unedo is also restricted to the autumn and closely controlled by moisture conditions (4). Severe water stress thus most likely precludes fruit ripening during the hot-dry Mediterranean summer (26), particularly in the warmer lowlands, and prevailing autumn ripening may be a response to predictable rainfall characteristic of the Mediterranean-type climate.

FRUIT SIZE There is a close correlation across habitats between means of fruit diameter of local species and body size of dispersers (70). Small-sized frugivores and small-fruited species predominate in lowland habitats, while larger-sized frugivores (mostly Turdus species) and larger-fruited plants predominate in highlands $(64,70,77,96,102,103,106,130,173)$. Altitudinal segregation of different-sized frugivores is unlikely to represent a response to variation in fruit size, as proportional contribution of small species to bird communities generally declines with elevation regardless of feeding habits $(2$, 123). This decline is probably a consequence of size-related differential ability to cope with adverse thermal environments. There is, however, evidence of selection by small birds in lowland habitats against large-fruited plant species and, within species, against large-fruited phenotypes. Percentage of fruit crops removed by birds declines significantly with increasing fruit diameter both among species (64) and among individuals within species $(78,107,110)$. These 
two levels of selection, operating concurrently, have presumably shaped fruit size distributions in lowlands via long-term processes, both demographic (consistent dispersal advantages of small-fruited over large-fruited species) and evolutionary (adaptive changes within species). The latter mechanism is supported by the observation that, in several plant genera with species that segregate altitudinally (e.g. Pistacia, Daphne, Phillyrea, Lonicera), lowland species invariably have smaller fruits than do highland congeners (70). In the comparative analysis of angiosperm fleshy fruits by Jordano (117), traits related to fruit size were the least influenced by phylogenetic correlations and the most closely correlated with type of dispersal agent.

NUTRITIONAL CHARACTERISTICS OF FRUITS Extensive studies have been conducted on the structural and nutritional characteristics of Mediterranean fleshy fruits $(36,57,75,94,95,97)$. The potential profitability of fruits to dispersal agents in a sample of southern Spanish species was shown by Herrera (57) not to differ significantly from that exhibited by a set of tropical species. Furthermore, almost all plant genera that have very lipid-rich fruits belong to plant families of tropical affinities (Oleaceae, Anacardiaceae, Lauraceae). In the genus Pistacia, for example, high lipid content has been found consistently in species from Israel (58\% of pulp dry mass) (97), southern France (50-61\%) (36), and southern Spain $(56-59 \%)(75,110)$. Other genera with lipid-rich fruits include Laurus, Olea, Rhus, Juniperus, Rubia, and Viburnum. As noted earlier, these fruits are essential for the maintenance of frugivory among overwintering dispersers. A high protein content has been also reported for some species $(36,75,97)$, but this should be interpreted with caution, because abundant nonprotein nitrogen compounds in fruits of many Mediterranean species may have led to inflated protein content estimates (95).

Nutritional characteristics of fruits are related to season of ripening. Average water content of pulp decreases, and lipid content increases, from summerthrough autumn- to winter-ripening species $(36,61)$. Species ripening in summer produce fruits characterized by water- and carbohydrate-rich pulps, while lipid-rich fruit pulps are predominantly found among autumn- and winter-fruiting ones. Energy-rich fruits are thus most abundant precisely at a time of year when the energy demands of dispersers are probably highest, while those providing most water are more frequent during the summer, when water availability to birds is at its yearly minimum. This seasonal matching between fruit attributes and disperser requirements was interpreted by Herrera (61) in terms of ("diffuse") coevolution between plants and birds. Results of later investigations, however, cast doubt on this interpretation. Characteristics of Mediterranean fleshy fruits, and especially nutritional ones, are closely correated with phylogeny $(75,82,117)$, and these traits have apparently undergone little evolutionary change over extended geological periods $(74,78)$. Autumn- 
winter ripening plants like Pistacia, Olea, and Laurus thus most likely have very lipid-rich fruits not because of their particular ripening seasons in the Mediterranean, but because the lineages involved intrinsically have fruits with these characteristics, regardless of habitat type or fruiting phenology. The importance of phylogenetic correlations as determinants of the characteristics of Mediterranean fruits has been demonstrated by Herrera (82). Interspecific variation in fruit shape among vertebrate-dispersed plants of the Iberian Peninsula did not depart significantly from that predicted by an allometry-based null hypothesis, and deviations of individual species from the allometric relationship were unrelated to dispersal mode and originated from genus and species-specific variation in fruit shape (see also 117).

\section{Bird Traits}

FRUGIVORE ABUNDANCE AND RESOURCE TRACKING High rates of fruit removal experienced by most Mediterranean plants are a consequence of extensive frugivory by dispersers, but also of disperser abundance and ability to track spatio-temporal variations in fruit abundance. Variation among habitats in success of fruit removal, particularly with elevation (Table 1), are due to concurrent variation in absolute and relative abundances of dispersers and fruit predators $(55,64,70,85,116)$. During autumn-winter, dispersers were 3.5 times more abundant in lowland than highland southern Spanish habitats, accounting for $79 \%$ of frugivorous bird populations in the former but only $52 \%$ in the latter (64). In lowland habitats, species of overwintering dispersers may reach extraordinary densities-up to 154 birds/10 ha (106).

Fruit production is smaller and fluctuates more across years in highland than lowland habitats $(76,85,106,107,113,115)$. In highlands, between-year variation in abundance of small-sized dispersers (Sylvia, Erithacus) does not track variation in fruit supply (76), but abundance of larger-sized dispersers (Turdus) generally does (115). Although there is also some annual variation, fruit production is more predictable in lowlands $(48,106,107,139,142)$. There, abundance of both small- and larger-sized dispersers parallels annual changes in fruit supply $(106,142)$. Although individual frugivorous birds tend to return to the same winter quarters in consecutive years (124), their nomadic behavior enables them to track spatio-temporal variation in fruit availability at a regional scale $(31,140)$. Individuals of Sylvia atricapilla overwintering in the Mediterranean Basin wander over hundreds of kilometers during the same winter season (120).

TROPHIC ADAPTATIONS Mediterranean avian dispersers are seasonal frugivores that shift from an insect-dominated diet in spring-summer to a fruit- 
dominated one in autumn-winter. At least in some species, this seasonal dietary shift is not a short-term response to increased availability of fruits but is controlled by an endogenous rhythm of food preferences $(8,12,148)$. Garden (Sylvia borin) and Blackcap ( $S$. atricapilla) warblers kept under controlled laboratory conditions with unlimited availability of various food items exhibited seasonal changes in food preference, shifting spontaneously from insectivory to frugivory in late summer $(8,12)$. In the Garden Warbler, the shift to frugivory is accompanied by hyperphagia, increased assimilation efficiency, food selection-mediated compensation for specific nutrient deficiencies of fruits, and regulation of daily food intake (7).

Faced with the same abundant fruit supply, major seed dispersers (Sylvia, Erithacus, Turdus) rely much more heavily on fruits for food locally than do coexisting fruit predators (finches and titmice; 64, 85). This difference is partly attributable to morphological preadaptations of dispersers that enable them to handle and swallow whole fruits efficiently. Dispersers tend to have flatter and broader bills than do fruit predators, and they have a wider mouth relative to bill width $(65,108)$. Functional digestive adaptations, however, seem to play the main role in allowing sustained and heavy frugivory by major dispersers $(65,108)$. Gut passage time of legitimate dispersers is considerably shorter than that of fruit predators of similar body size $(65,104,108)$. The dry mass of nutritious material obtainable per mass unit of fresh whole fruit ingested is very low, as it is "diluted" by high water content and indigestible seeds. An ability to process fruits rapidly is thus essential for dispersers to exploit extensively these superabundant but, individually, minimally rewarding items. The shorter gut passage times of Mediterranean dispersers reflect faster food passage rates, not shorter intestine lengths. In fact, dispersers have proportionally longer intestines than do nonfrugivores and fruit predators (108), a characteristic that probably enhances assimilatory efficiency (147). In Pycnonotus leucogenys, intestine length varies seasonally and is directly correlated with the proportion of fruits in the diet (3).

Another factor that may contribute to the extensive frugivory of major dispersers is their tolerance of secondary compounds in the pulp of ripe fruits $(11,62,95)$. Seuter $(145)$ found tolerance to the alkaloid atropine (occurring in Atropa spp. fruits) to be $10^{3}$ times greater in Turdus merula than in humans. Fruit predators only rarely include toxic fruits in their diet, while legitimate dispersers consume them abundantly; and a close correlation exists across disperser species between degree of frugivory and occurrence of toxic fruits in the diet (72). Furthermore, degree of frugivory is correlated with the frequency of chemically defended, aposematic insects in the diet (72), which also suggests the existence of enhanced tolerance to toxic metabolites among Mediterranean dispersers. 


\section{LIMITS ON PLANT ADAPTATION TO DISPERSERS}

Mediterranean frugivorous birds are able to discriminate among co-occurring fruit species, individual fruiting plants within species, and fruits within individual fruit crops $(59,64,78,107)$. Of these three selection levels, the second is apt to have evolutionary consequences for the plant species involved (133). Furthermore, disperser species vary in the quantity and quality of dispersal effected $(84,99,144)$, and this variation provides the raw material for plants to evolve adaptations to the one or few taxa providing the best dispersal services. Why, then, are adaptations of Mediterranean plants to their current dispersers so infrequent, in contrast with the situation occurring among birds? Limitations on plant adaptation to dispersers that are inherent to most or all plant-disperser systems have been reviewed elsewhere $(73,74,91,170)$. I briefly consider two further reasons for Mediterranean systems.

With only minor exceptions (Viburnum tinus and highland junipers, which rely for dispersal on $E$. rubecula and Turdus torquatus, respectively; 34, 64, 115, 173), Mediterranean plants have their seeds dispersed by an array of bird species, and degrees of dependence on particular dispersers fluctuate among years and sites $(37,50,55,64,96,107,116)$. Variation at different temporal and spatial scales in the composition and relative abundance of the dispersers and fruit predators that interact with a given plant, along with incongruence between the geographical distributions of plant and bird species $(55,77,115,116)$, limit the possibilities of selection by particular dispersers on dispersal-related traits.

Most studies focusing on patterns of phenotypic selection exerted by Mediterranean dispersers on dispersal-related plant traits have shown that, although individual variation in these traits actually translates into differential seed dispersal success, such variation has only a minor influence on final reproductive output of the plants $(78,85,107,110,166)$. Individual variation in fruit traits explains only $1.8 \%, \approx 2 \%$, and $0.5-2.3 \%$ of the variance in reproductive output in Pistacia lentiscus, Osyris quadripartita, and Phillyrea latifolia, respectively $(78,85,110)$. The overwhelming influence on reproductive output of differences in flower production and crop size, and the effects of multiple interactions with vertebrate and invertebrate fruit predators, are the main reasons for the negligible influence of selection by dispersers on the realized fecundity of Mediterranean plants. Under this regime of extremely low selection intensities by avian dispersers, responses of plants to selection on fruit or fruiting characteristics are unlikely, and strong phylogenetic correlations of fruit traits are not surprising.

\section{HISTORY OF BIRD DISPERSAL IN THE MEDITERRANEAN}

The contemporary flora of the Mediterranean Basin represents a historically heterogeneous assortment of lineages with varied origins in time and space 
$(83,134,137)$. Some plant genera were present in the region well before the initiation of the Mediterranean-type climatic conditions in the Pliocene, while others appeared much more recently. The first appearances in the fossil record of genuinely Mediterranean fleshy-fruited genera are spread over the Eocene (e.g. Chamaerops, Smilax), Oligocene (e.g. Arbutus, Olea), and Miocene (e.g. Pistacia, Phillyrea) (see 134 for review).

Lineage age of extant Mediterranean woody plants is correlated with several aspects of their reproductive biology, including seed dispersal (83). The fleshy fruit-producing habit is extremely infrequent among those lineages that arose in, or immigrated to, truly Mediterranean-climate scenarios. In this group of young lineages, only $5.6 \%$ of genera produce fleshy fruits and are bird-dispersed. Other taxa, in contrast, are the remnants of the tropical and subtropical flora that was widespread in west-central and southern Europe when the region was still tropical (Refs. in 83). In this group of old lineages, $94.4 \%$ of genera produce fleshy fruits. Most old, fruit-producing lineages presently occur in lowland and mid-elevation habitats, where they are responsible for increased familial diversity of local fleshy-fruited species assemblages. Furthermore, the group of old lineages includes all the distinctive lipid-rich, autumn-winter fruiting plants that are essential in maintaining the frugivorous diet of major avian seed dispersers (Pistacia, Olea).

Differences between pre-Mediterranean lineages in seed dispersal method seem to have led to differential extinction probabilities from the initiation of the Mediterranean-type climate until present. Among woody plant genera that occurred in the Mediterranean region in the Pliocene, $47.4 \%$ of those producing fleshy fruits have become extinct, compared to $69.2 \%$ extinction among genera with other seed dispersal methods $\left(P=0.061, \chi^{2}\right.$ test; computations use data from Ref. 83). This trend suggests that fleshy-fruited lineages have some demographic advantage over dry-fruited ones that has allowed them to persist longer in the region despite changes in environmental conditions. These possible advantages, however, are not attributable to the action of current dispersal agents. In comparison with their food plants, both the species of Mediterranean avian dispersers and their migratory behavior are young. Avian fossils referable to recent species of frugivores (including Turdus and Sylvia spp.) do not appear in Europe until the Pleistocene (122), and this recent origin is consistent with biogeographical interpretations (17) and estimates of lineage age obtained from DNA hybridization studies (146). In addition, the present global pattern of seasonal migrations must have been established even more recently, during the 15,000-20,000 years since the peak of the last glaciation (124). The migratory behavior of overwintering species such as Sylvia atricapilla and Erithacus rubecula has a genetic basis (13-15), and microevolutionary changes may take place rapidly in response to modifications in geographical patterns of food availability. Populations of S. atricapilla breeding in western Europe 
have evolved a new, genetically based migratory behavior in only three decades in response to improved wintering conditions in the new British wintering areas (14).

\section{CONCLUSION}

While there is substantial evidence that Mediterranean avian seed dispersers have evolved physiological, digestive, and behavioral adaptations to take advantage of the abundant and profitable fruit supply in the region, analogous evidence is lacking for fruiting plants. Interspecific variation in fruiting phenology, fruit shape, nutritional composition of fruits, and structural fruit characteristics of Mediterranean plants are more closely tied to phylogeny or to the abiotic environment than to the current disperser/dispersal environment $(49,75,82,117)$. Mediterranean fleshy-fruited plants and their current avian dispersers lack a common history of interaction; the birds presumably evolved their present trophic and migratory adaptations in response to a previous ecological scenario characterized by mild winters and abundant and energetically profitable fruits.

It once seemed intuitive to expect that, in ecological interactions in which counterparts mutually benefit from participating in the interaction, reciprocal adaptations enhancing these benefits should evolve ("coevolution"; 100). The earliest evolutionary treatments of plant-animal seed dispersal systems were imbued with this view $(92,125,150)$, but later studies showed that, for a variety of reasons, plant-disperser coevolution was unlikely to occur $(73,74$, $91,170)$. Studies on Mediterranean seed dispersal systems not only support this latter view, they also indicate that extremely efficient plant-disperser mutualisms do not require, and thus are not evidence for, mutual evolutionary adjustments of participants.

In ecological and evolutionary time, current Mediterranean dispersal systems seem to have been shaped through 1) actual adaptations of morphologically and behaviorally preadapted dispersers to preexisting plant resources, and 2) disperser-mediated processes occurring at an ecological time scale and based on differential recruitment of plant species as a function of disperser preferences. These adjustments are based on ecological, not evolutionary, processes and are best described as instances of "ecological fitting" (101) or "habitat shaping" (70). On the plant side, the prevalence of historical effects (long-term persistence of traits evolved in temporally and ecologically distant scenarios; 83) apparently reflects a series of ecological limitations inherent to the interaction between plants and dispersal agents that constrain the adaptation of plants to dispersers. A practical corollary following from this review is that future investigations on the evolutionary ecology of Mediterranean plant-disperser systems should concentrate more on the animal than on the plant side 
of the interaction, for it is among dispersers that adaptive explanations related to present-day environments seem both most straightforward and best justified.

\section{ACKNOWLEDGMENTS}

I am indebted to Pedro Jordano for valuable discussion, assistance with the literature, and unpublished data; to him, Conchita Alonso, Juan A. Amat, José L. Yela, and an anonymous reviewer for critical comments on the manuscript; and to Javier Guitián, Pedro Rey, and Anna Traveset for generously supplying preprints or unpublished information. While preparing this paper, I was funded by DGICYT grant PB91-0114.

Any Annual Review chapter, as well as any article cited in an Annual Review chapter, may be purchased from the Annual Reviews Preprints and Reprints service. 1-800-347-8007; 415-259-5017; email: arpr Cclass.org

\section{Literature Cited}

1. Adar M, Safriel UN, Izhaki I. 1992. Removal of the green fruit of Asparagus aphyllus by birds- seed predation or dispersal? In Plant-Animal Interactions in Mediterranean-Type Ecosystems, ed. CA Thanos, pp. 281-86. Athens: Univ. Athens

2. Affre G. 1980 . Distribution altitudinale des oiseaux dans l'est des Pyrenees françaises. Oiseau R.F.O. 50:1-22

3. Al-Dabbagh KY, Jiad JH, Waheed IN. 1987. The influence of diet on the intestine length of the white-cheeked bulbul. Ornis Scand. 18:150-52

4. Arianoutsou-Faraggitaki M, Psaras G, Christodoulakis N. 1984. The annual rhythm of cambial activity in two woody species of the Greek "Maquis." Flora 175:221-29

5. Aronne C, Wilcock CC. 1994. First evidence of myrmecochory in fleshyfruited shrubs of the Mediterranean region. New Phytol. 127:781-88

6. Arroyo J, Marañón T. 1990. Community ecology and distributional spectra of Mediterranean shrublands and heathlands in southern Spain. J. Biogeogr. 17:163-76

7. Bairlein F. 1991. Nutritional adaptations to fat deposition in the long-distance migratory garden warbler Sylvia borin. Acta 20th Congr. Int. Ornithol., Christchurch, pp. 2149-58

8. Bairlein F, Gwinner E. 1994. Nutritional mechanisms and temporal control of migratory energy accumulation in birds. Annu. Rev. Nutr. 14:187-215
9. Barnea A, Yom-Tov Y, Friedman J. 1990. Differential germination of two closely related species of Solanum in response to bird ingestion. Oikos 57: 222-28

10. Barnea A, Yom-Tov Y, Friedman J. 1991. Does ingestion by birds affect seed germination? Funct. Ecol. 5:394402

11. Barnea A, Harborne JB, Pannell C. 1993. What parts of fleshy fruits contain secondary compounds toxic to birds and why? Biochem. Syst. Ecol. 21:421-29

12. Berthold P. 1976. Animalische und vegetabilische Ernährung omnivorer Singvogelarten: Nahrungsbevorzugung, Jahresperiodik der Nahrungswahl, physiologische und ökologische Bedeutung. J. Ornithol. 117:145-209

13. Berthold P, Querner U. 1981 . Genetic basis of migratory behavior in European warblers. Science 212:77-79

14. Berthold P, Helbig AJ, Mohr G, Querner U. 1992. Rapid microevolution of migratory behaviour in a wild bird species. Nature 360:668-69

15. Biebach H. 1983. Genetic determination of partial migration in the European Robin (Erithacus rubecula). Auk 100: 601-6

16. Biebach H, Friedrich W, Heine G. 1986. Interaction of body-mass, fat, foraging and stopover period in trans-Sahara migrating passerine birds. Oecologia 69: 370-79

17. Blondel J. 1982. Caractérisation et mise 
en place des avifaunes dans le bassin méditerranéen. Ecol. Medit. 8:253-72

18. Calisti M, Ciampalini B, Lovari S, Lucherini M. 1990. Food habits and trophic niche variation of the red fox Vulpes vulpes (L., 1758) in a Mediterranean coastal area. Rev. Ecol. (Terre Vie) 45:309-20

19. Calvario E, Fraticelli F. 1986. Rubia peregrina berries in the winter food of Robins Erithacus rubecula. Avocetta 10: 115-18

20. Chiarucci A, Pacini E, Loppi S. 1993. Influence of temperature and rainfall on fruit and seed production of Arbutus unedo L. Bot. J. Linn. Soc. 111:71-82

21. Cramp S, ed. 1988. Handbook of the Birds of Europe, the Middle East and North Africa. Vol. 5. Tyrant Flycatchers to Thrushes. Oxford: Oxford Univ. Press. 1063 pp.

22. Cramp S, ed. 1992. Handbook of the Birds of Europe, the Middle East and North Africa. Vol. 6. Warblers. Oxford: Oxford Univ. Press. 728 pp.

23. Cuadrado M, Rodriguez M, Arjona S. 1989. Fat and weight variations of Blackcaps wintering in southern Spain. Ring. \& Migr. 10:89-97

24. Darwin C. 1862. On the Various Contrivances by Which British and Foreign Orchids Are Fertilised by Insects. London: Murray. 300 pp.

25. Darwin C. 1877. The Different Forms of Flowers on Plants of the Same Species. London: Murray. 352 pp.

26. de Lillis M, Fontanella A. 1992. Comparative phenology and growth in different species of the Mediterranean maquis of central Italy. Vegetatio 99: 83-96

27. Debussche M. 1985. Rôle des oiseaux disseminateurs dans la germination des graines de plantes à fruits charnus en région méditerranéenne. Acta Oecol., Oecol. Plant. 6:365-74

28. Debussche M. 1988. La diversité morphologique des fruits charnus en Languedoc méditerranéen: relations avec les caractéristiques biologiques et la distribution des plantes, et avec les disséminateurs. Acta Oecol., Oecol. Gener. 9:37-52

29. Debussche M, Escarre J, Lepart J. 1982. Ornithochory and plant succession in mediterranean abandoned orchards. Vegetatio 48:255-66

30. Debussche M, Isenmann P. 1983. La consommation des fruits chez quelques fauvettes méditerranéennes (Sylvia melanocephala, S. cantillans, S. hortensis et $S$. undata ) dans la région de Montpellier (France). Alauda 51:302-8
31. Debussche M, Isenmann P. 1984. Origine et nomadisme des fauvettes à tête noire (Sylvia atricapilla) hivernant en zone méditerranéenne française. Oiseau R.F.O. 54:101-7

32. Debussche $M$, Isenmann $P$. 1985. Le régime alimentaire de la Grive musicienne (Turdus philomelos) en automne et en hiver dans les garrigues de Montpellier (France méditerranénne) et ses relations avec l'ornithochorie. Rev. Ecol. (Terre Vie) 40:379-88

33. Debussche $M$, Isenmann $P$. 1985. An example of Redwing diet in a Mediterranean wintering area. Bird Study 32: 152-53

34. Debussche M, Isenmann P. 1985. Frugivory of transient and wintering European robins Erithacus rubecula in a Mediterranean region and its relationship with ornithochory. Holarctic Ecol. 8:157-63

35. Debussche M, Lepart J, Molina J. 1985. La dissémination des plantes à fruits charnus par les oiseaux: rôle de la structure de la végétation et impact sur la succession en région méditerranéenne. Acta Oecol., Oecol. Gener. 6:65-80

36. Debussche $M$, Cortez J, Rimbault I. 1987. Variation in fleshy fruit composition in the Mediterranean region: the importance of ripening season, lifeform, fruit type and geographical distribution. Oikos 49:244-52

37. Debussche M, Isenmann P. 1989. Fleshy fruit characters and the choices of bird and mammal seed dispersers in a Mediterranean region. Oikos 56:327-38

38. Debussche M, Isenmann P. 1990. Introduced and cultivated fleshy-fruited plants: consequences for a mutualistic Mediterranean plant-bird system. In Biological Invasions in Europe and the Mediterranean Basin, ed. F di Castri, AJ Hansen, M Debussche, pp. 399-416. Dordrecht: Kluwer

39. Debussche M, Isenmann P. 1992. A Mediterranean bird disperser assemblage: composition and phenology in relation to fruit availability. Rev. Ecol. (Terre Vie ) 47:411-32

40. Debussche M, Lepart J. 1992. Establishment of woody plants in mediterranean old fields: opportunity in space and time. Landscape Ecol. 6:133-45

41. Debussche M, Isenmann P. 1994. Birddispersed seed rain and seedling establishment in patchy Mediterranean vegetation. Oikos 69:414-26

42. di Castri F. 1981. Mediterranean-type shrublands of the world. In Ref. 43, pp. 1-52

43. di Castri F, Goodall DW, Specht RL, 
eds. 1981. Ecosystems of the World. Vol. 11. Mediterranean-Type Shrublands. Amsterdam: Elsevier. 643 pp.

44. Estrada A, Fleming TH, eds. 1986. Frugivores and Seed Dispersal. Dordrecht: Junk. 392 pp.

45. Ferns PN. 1975. Feeding behaviour of autumn passage migrants in north east Portugal. Ring. \& Migr. 1:3-11

46. Fleming TH, Estrada A, eds. 1993. Frugivory and Seed Dispersal: Ecological and Evolutionary Aspects. Dordrecht: Kluwer. 392 pp.

47. Fortuna P. 1991. Studio sull'alimentazione della popolazione di Stomi svernante nella citta di Roma. Avocetta 15: 25-31

48. Fraticelli F, Gustin M. 1986. Blackberries, Rubus ulmifolius, in the autumnal feeding of blue tits, Parus caeruleus. Riv. Ital. Om. 56:114-16

49. Fuentes M. 1992. Latitudinal and elevational variation in fruiting phenology among western European bird-dispersed plants. Ecography 15:177-83

50. Fuentes M. 1994. Diets of fruit-eating birds: What are the causes of interspecific differences? Oecologia 97:134-42

51. Gardiazábal A. 1990. Untersuchungen zur Ókologie rastender Kleinvögel im Nationalpark von Dofiana, (Spanien): Ernährung, Fettdeposition Zugstrategie. PhD thesis. Univ. Köln. 158 pp.

52. Genard M, Lescourret F. 1985. Le sanglier (Sus scrofa scrofa L.) et les diaspores dans le sud de la France. Rev. Ecol. (Terre Vie ) 40:343-53

53. González-Solís J, Ruiz X. 1990. Alimentación do Turdus philomelos en los olivares mediterráneos ibéricos durante la migración otoñal. Misc. Zool. 14:195206

54. Guitián J, Sánchez JM. 1992. Seed dispersal spectra of plant communities in the Iberian Peninsula. Vegetatio 98:15764

55. Guitián J, Fuentes M, Bermejo T, López B. 1992. Spatial variation in the interactions between Prunus mahaleb and frugivorous birds. Oikos 63:125-30

56. Hernández A. 1990. Observaciones sobre el papel del lagarto ocelado (Lacerta lepida Daudin), el erizo (Erinaceus europaeus L.) y el tejón (Meles meles L.) en la dispersión de semillas. Doñana Acta Vert. 17:235-42

57. Herrera CM. 1981. Are tropical fruits more rewarding to dispersers than temperate ones? Am. Nat. 118:896-907

58. Herrera CM. 1981. Fruit food of Robins wintering in southern Spanish mediterranean scrubland. Bird Study 28:115-22
59. Herrera CM. 1981. Fruit variation and competition for dispersers in natural populations of Smilax aspera. Oikos 36: $51-58$

60. Herrera CM. 1982. Datos sobre la dieta frugivora del Mirlo (Turdus merula) en dos localidades del sur de España. Doñana Acta Vert. 8:306-10

61. Herrera CM. 1982. Seasonal variation in the quality of fruits and diffuse coevolution between plants and avian dispersers. Ecology 63:773-85

62. Herrera CM. 1982. Defense of ripe fruits from pests: its significance in relation to plant-disperser interactions. Am. Nat. 120:218-41

63. Herrera CM. 1983. Coevolución de plantas y frugivoros: la invernada mediterránea de algunos paseriformes. Alytes 1:177-90

64. Herrera CM. 1984. A study of avian frugivores, bird-dispersed plants, and their interaction in Mediterranean scrublands. Ecol. Monogr. 54:1-23

65. Herrera CM. 1984. Adaptation to frugivory of Mediterranean avian seed dispersers. Ecology 65:609-17

66. Herrera CM. 1984. Tipos morfológicos y funcionales en plantas del matorral mediterráneo del sur de España. Studia Oecol. 5:7-33

67. Herrera CM. 1984. Avian interference of insect frugivory: an exploration into the plant-bird-fruit pest evolutionary triad. Oikos 42:203-10

68. Herrera CM. 1984. Selective pressures on fruit seediness: differential predation of fly larvae on the fruits of Berberis hispanica. Oikos 42:166-70

69. Herrera CM. 1984. Seed dispersal and fitness determinants in wild rose: combined effects of hawthorn, birds, mice, and browsing ungulates. Oecologia 63: 386-93

70. Herrera CM. 1985. Habitat-consumer interactions in frugivorous birds. In Habitat Selection in Birds, ed. ML Cody, pp. 341-65. New York: Academic

71. Herrera CM. 1985. Predispersal reproductive biology of female Osyris quadripartita (Santalaceae), a hemiparasitic dioecious shrub of Mediterranean scrublands. Bot. J. Linn. Soc. 90: 113-27

72. Herrera CM. 1985. Aposematic insects as six-legged fruits: incidental short-circuiting of their defense by frugivorous birds. Am. Nat. 126:286-93

73. Herrera CM. 1985. Determinants of plant-animal coevolution: the case of mutualistic dispersal of seeds by vertebrates. Oikos 44:132-41 
74. Herrera CM. 1986. Vertebrate-dispersed plants: Why they don't behave the way they should. In Ref. 44, pp. 5-18

75. Herrera CM. 1987. Vertebrate-dispersed plants of the Iberian Peninsula: a study of fruit characteristics. Ecol. Monogr. 57:305-31

76. Herrera CM. 1988. Variaciones anuales en las poblaciones de pajaros frugívoros y su relación con la abundancia de frutos. Ardeola 35:135-42

77. Herrera CM. 1988. Avian frugivory and seed dispersal in Mediterranean habitats: regional variation in plant-animal interaction. In Acta XIX Congressus Internationalis Ornithologici, Vol. 1, ed. H Ouellet, pp. 509-17. Ottawa: Univ. Ottawa Press

78. Herrera CM. 1988. The fruiting ecology of Osyris quadripartita: individual variation and evolutionary potential. Ecology 69:233-49

79. Herrera CM. 1988. Habitat-shaping, host plant use by a hemiparasitic shrub, and the importance of gut fellows. Oikos $51: 383-86$

80. Herrera CM. 1988. Plant size, spacing patterns, and host-plant selection in Osyris quadripartita, a hemiparasitic dioecious shrub. J. Ecol. 76:995-1006

81. Herrera CM. 1989. Frugivory and seed dispersal by carnivorous mammals, and associated fruit characteristics, in undisturbed Mediterranean habitats. Oikos 55:250-62

82. Herrera CM. 1992. Interspecific variation in fruit shape: allometry, phylogeny, and adaptation to dispersal agents. Ecology 73:1832-41

83. Herrera CM. 1992. Historical effects and sorting processes as explanations for contemporary ecological patterns: character syndromes in Mediterranean woody plants. Am. Nat. 140:421-46

84. Herrera CM, Jordano P. 1981. Prunus mahaleb and birds: the high-efficiency seed dispersal system of a temperate fruiting tree. Ecol. Monogr. 51:20318

85. Herrera CM, Jordano P, López-Soria L, Amat JA. 1994. Recruitment of a mastfruiting, bird-dispersed tree: bridging frugivore activity and seedling establishment. Ecol. Monogr. 64:315-44

86. Herrera J. 1984. Vegetación del Valle del Guadahornillos (Sierra de Cazorla, Jaén). Studia Oecol. 5:77-96

87. Herrera J. 1986. Flowering and fruiting phenology in the coastal shrublands of Doñana, south Spain. Vegetatio 68: 9198

88. Herrera J. 1987. Flower and fruit biology in southern Spanish Mediterranean shrublands. Ann. Miss. Bot. Gard. 74: 69-78

89. Herrera J. 1987. Biología reproductiva de algunas especies del matorral de Doñana. Anal. Jard. Bot. Madrid 44: 483-97

90. Houssard C, Escarré J, Romane F. 1980. Development of species diversity in some mediterranean plant communities. Vegetatio 43:59-72

91. Howe HF. 1984. Constraints on the evolution of mutualisms. Am. Nat. 123: 764-77

92. Howe HF, Estabrook GF. 1977. On intraspecific competition for avian dispersers in tropical trees. Am. Nat. 111: 817-32

93. Ioale P, Benvenuti S. 1982. Seasonal and diurnal variation of weight in four passeriformes in autumn and winter. Avocetta 6:63-74

94. Izhaki I. 1992. A comparative analysis of the nutritional quality of mixed and exclusive fruit diets for yellow-vented bulbuls. Condor 94:912-23

95. Izhaki I. 1993. Influence of nonprotein nitrogen on estimation of protein from total nitrogen in fleshy fruits. J. Chem. Ecol. 19:2605-15

96. Izhaki I, Safriel UN. 1985. Why do fleshy-fruit plants of the mediterranean scrub intercept fall- but not spring-passage of seed-dispersing migratory birds? Oecologia 67:40-43

97. Izhaki I, Safriel UN. 1989. Why are there so few exclusively frugivorous birds? Experiments on fruit digestibility. Oikos 54:23-32

98. Izhaki I, Safriel UN. 1990. The effect of some Mediterranean scrubland frugivores upon germination pattern. J. Ecol. 78:56-65

99. Izhaki I, Walton PB, Safriel UN. 1991. Seed shadow generated by frugivorous birds in an eastern Mediterranean scrub. J. Ecol. 79:575-90

100. Janzen DH. 1980. When is it coevolution? Evolution 34:611-12

101. Janzen DH. 1985. On ecological fitting. Oikos 45:308-10

102. Jordano P. 1981. Alimentación y relaciones tróficas entre los passeriformes en paso otoñal por una localidad de Andalucía central. Doñana Acta Vert. 8:103-24

103. Jordano P. 1982. Migrant birds are the main seed dispersers of blackberries in southern Spain. Oikos 38:183-93

104. Jordano P. 1984. Relaciones entre plantas $y$ aves frugivoras en el matorral mediterráneo del área de Doñana. $\mathrm{PhD}$ thesis. Univ. Sevilla. 284 pp.

105. Jordano P. 1984. Seed weight variation 
and differential avian dispersal in blackberries Rubus ulmifolius. Oikos 43:14953

106. Jordano P. 1985. El ciclo anual de los paseriformes frugivoros en el matorral mediterráneo del sur de España: importancia de su invernada y variaciones interanuales. Ardeola 32:69-94

107. Jordano P. 1987. Avian fruit removal: effects of fruit variation, crop size, and insect damage. Ecology 68:1711-23

108. Jordano P. 1987. Frugivory, external morphology and digestive system in mediterranean sylviid warblers Sylvia spp. Ibis 129:175-89

109. Jordano P. 1988. Diet, fruit choice and variation in body condition of frugivorous warblers in Mediterranean scrubland. Ardea 76:193-209

110. Jordano P. 1989. Predispersal biology of Pistacia lentiscus (Anacardiaceae): cumulative effects on seed removal by birds. Oikos 55:375-86

111. Jordano P. 1989. Variación de la dieta frugívora otoño-invernal del Petirrojo (Erithacus rubecula ): efectos sobre la condición corporal. Ardeola 36:16183

112. Jordano P. 1990. Utilización de los frutos de Pistacia lentiscus (Anacardiaceae) por el verderón común (Carduelis chloris). In Principios en etologia, ed. L Arias, P Recuerda, T Redondo, pp. 145-53. Córdoba: Monte Piedad

113. Jordano P. 1991. Gender variation and expression of monoecy in Juniperus phoenicea (L.) (Cupressaceae). Bot. Gaz. 152: 76-485

114. Jordano P. 1992. Fruits and frugivory. In Seeds. The Ecology of Regeneration in Plant Communities, ed. M Fenner, pp. 105-56. London: CAB Int.

115. Jordano P. 1993. Geographical ecology and variation of plant-seed disperser interactions: southern Spanish junipers and frugivorous thrushes. In Ref. 46, pp. 85-104

116. Jordano P. 1994. Spatial and temporal variation in the avian-frugivore assemblage of Prunus mahaleb: patterns and consequences. Oikos 71:479-91

117. Jordano P. 1995. Angiosperm fleshy fruits and seed dispersers: a comparative analysis of adaptation and constraints in plant-animal interactions. Am. Nat. 145: 163-91

118. Jordano P, Herrera CM. 1981. The frugivorous diet of Blackcap populations Sylvia atricapilla wintering in southern Spain. Ibis 123:502-7

119. Jordano P, Herrera CM. 1995. Shuffling the offspring: uncoupling and spatial discordance of multiple stages in vertebrate seed dispersal. Ecoscience. In press

120. Klein H, Berthold P, Gwinner E. 1973. Der Zug europäischer Garten und Mönchsgrasmücken (Sylvia borin und S. atricapilla). Vogelwarte 27:73-134

121. Krisi BO, Debussche M. 1988. The fate of flowers and fruits of Comus sanguinea $\mathrm{L}$. in three contrasting Mediterranean habitats. Oecologia 74:592600

122. Lambrecht K. 1964. Handbuch der Palaeornithologie. Amsterdam: Asher. $1024 \mathrm{pp}$.

123. Lebreton $P$, Broyer J. 1981. Contribution a l'étude des relations avifaune/altitude. I. Au niveau de la région Rhône-Alpes. Oiseau R.F.O. 51:265-85

124. Lövei GL. 1989. Passerine migration between the Palaearctic and Africa. Current Omithol. 6:143-74

125. McKey D. 1975. The ecology of coevolved seed dispersal systems. In Coevolution of Animals and Plants, ed. LE Gilbert, PH Raven, pp. 159-91. Austin: Univ. Texas Press

126. Ménard N. 1985. Le régime alimentaire de Macaca sylvanus dans differents habitats d'Algerie. I. Régime en chênaie decidue. Rev. Ecol. (Terre Vie) 40:45169

127. Ménard N, Vallet D. 1986. Le régime alimentaire de Macaca sylvanus dans differents habitats d'Algerie: II. Régime en forêt sempervirente et sur les sommets rocheux. Rev. Ecol. (Terre Vie) 41:173-92

128. Muñoz Reinoso JC. 1993. Consumo de gálbulos de sabina (Juniperus phoenicea ssp. turbinata Guss, 1891) y dispersión de semillas por el conejo (Oryctolagus cuniculus L.) en el Parque Nacional de Doñana. Doñana Acta Vert. 20:49-58

129. Nogales M, Hernández EC. 1994. Interinsular variations in the spring and summer diet of the Raven Corvus corax in the Canary Islands. Ibis 136:441-47

130. Obeso JR. 1985. Comunidades de passeriformes y frugivorismo en altitudes medias de la Sierra de Cazorla. $\mathrm{PhD}$ thesis. Univ. Oviedo. 475 pp.

131. Obeso JR. 1986. Alimentación del zorzal charlo (Turdus viscivorus ) en la Sierra de Cazorla. Doñana Acta Vert. 13:95-102

132. Obeso JR. 1989. Fruit removal and potential seed dispersal in a southern Spanish population of Berberis vulgaris ssp. australis (Berberidaceae). Acta Oecol., Oecol. Plant. 10:321-28

133. Obeso JR, Herrera CM. 1994. Inter- and intraspecific variation in fruit traits 
in co-occurring vertebrate-dispersed plants. Int. J. Plant Sci. 155:382-87

134. Palamarev E. 1989. Paleobotanical evidences of the Tertiary history and origin of the Mediterranean sclerophyll dendroflora. Plant Syst. Evol. 162:93-107

135. Pigozzi G. 1992. Frugivory and seed dispersal by the European badger in a mediterranean habitat. J. Mamm. 73: 630-39

136. Polunin O, Walters M. 1985. A Guide to the Vegetation of Britain and Europe. Oxford: Oxford Univ. Press. 238 pp.

137. Pons A. 1981. The history of the Mediterranean shrublands. In Ref. 43, pp. 131-38

138. Rey PJ. 1992. Preadaptación de la avifauna frugivora invermante al cultivo del olivar. PhD thesis. Univ. Granada. 231 pp.

139. Rey PJ. 1993. The role of olive orchards in the wintering of frugivorous birds in Spain. Ardea 81:151-60

140. Rey PJ. 1995. Spatio-temporal variation in fruit availability and frugivorous bird abundance in Mediterranean olive orchards. Ecology In press

141. Ridley HN. 1930. The Dispersal of Plants Throughout the World. Ashford: Reeve. 744 pp.

142. Rodriguez M, Cuadrado M, Arjona S. 1986. Variation in the abundance of Blackcaps (Sylvia atricapilla) wintering in an olive (Olea europaea) orchard in southern Spain. Bird Study 33:81-86

143. Santos $T$, Tellería JL. 1994. Influence of forest fragmentation on seed consumption and dispersal of Spanish juniper Juniperus thurifera. Biol. Conserv. 70:129-34

144. Schupp EW. 1993. Quantity, quality and the effectiveness of seed dispersal by animals. In Ref. 46, pp. 15-29

145. Seuter F. 1970. Ist eine endozoische Verbreitung der Tollkirsche durch Amsel und Star möglich? Zool. Jahrb. Physiol. 75:342-59

146. Sibley CG, Ahlquist JE. 1990. Phylogeny and Classification of Birds. New Haven: Yale Univ. Press. 976 pp.

147. Sibly RM. 1981. Strategies of digestion and defecation. In Physiological Ecology, ed. CR Towsend, P Calow, Pp. 109-39. London: Blackwell

148. Simons D, Bairlein F. 1990. Neue Aspekte zur zugzeitlichen Frugivorie der Gartengrasmuicke (Sylvia borin). J. Ornithol. 131:381-401

149. Snow DW. 1965. A possible selective factor in the evolution of fruiting seasons in tropical forest. Oikos 15:27481

150. Snow DW. 1971. Evolutionary aspects of fruit-eating by birds. Ibis 113:194 202

150a. Soler JJ, Soler M. 1991. Análisis comparado del régimen alimenticio durante el perfodo otoño-invierno de tres especies de córvidos en un área de simpatría. Ardeola 38:69-89

151. Soler M, Pérez-González JA, Tejero E, Camacho I. 1988. Alimentación del zorzal alirrojo (Turdus iliacus ) durante su invernada en olivares de Jaen (sur de España). Ardeola 35:183-96

152. Soler M, Alcalá N, Soler JJ. 1990. Alimentación de la grajilla Corvus monedula en tres zonas del sur de España. Dofiana Acta Vert. 17:17-48

153. Soler M, Pérez-González JA, Soler JJ. 1991. Régimen alimenticio del mirlo comuacn (Turdus merula ) en el sureste de la Península Ibérica durante el perfodo otoño-invierno. Dofiana Acta Vert. 18:133-48

154. Deleted in proof

155. Suc JP. 1984. Origin and evolution of the Mediterranean vegetation and climate in Europe. Nature 307:429-32

156. Tellería JL, ed. 1988. Invernada de aves en la Península Ibérica. Madrid: Soc. Esp. Ornitol. 208 pp.

157. Thébaud C, Debussche M. 1992. A field test of the effects of infructescence size on fruit removal by birds in Viburnum tinus. Oikos 65:391-94

158. Thirgood JV. 1981. Man and the Mediterranean Forest. London: Academic Press. 194 pp.

159. Thomas DK. 1979. Figs as a food source of migrating Garden Warblers in southern Portugal. Bird Study 26:187-91

160. Thomson JN, Willson MF. 1979. Evolution of temperate fruit/bird interactions: phenological strategies. Evolution 33:973-82

161. Tomaselli R. 1976. La dégradation du maquis méditerranéenne. Not. Tech. $M A B$ 2:35-76

162. Traveset A. 1992. Production of galls in Phillyrea angustifolia induced by cecidomyiid flies. In Plant-Animal Interactions in Mediterranean-Type Ecosystems, ed. CA Thanos, pp. 198-204. Athens: Univ. Athens

163. Traveset A. 1993. Weak interactions between avian and insect frugivores: the case of Pistacia terebinthus $L$. (Anacardiaceae). In Ref. 46, pp. 191203

164. Traveset A. 1994. The effect of Agonoscena targionii (Licht.) (Homoptera: Psylloidea) on seed production by Pistacia terebinthus L. Oecologia 98: 72-75

165. Traveset A. 1994. Influence of type 
of avian frugivory on the fitness of Pistacia terebinthus L. Evol. Ecol. 8:618-27

166. Traveset A. 1994. Cumulative effects on the reproductive output of Pistacia terebinthus (Anacardiaceae). Oikos 71: 152-62

167. Traveset A. 1995. Seed dispersal of Cneorum tricoccon L. (Cneoraceae) by lizards and mammals in the Balearic Islands. Acta Oecol. In press

168. Valido A, Nogales M. 1994. Frugivory and seed dispersal by the lizard Gallotia galloti (Lacertidae) in a xeric habitat of the Canary Islands. Oikos 70: 40311

169. van der Pijl L. 1972. Principles of Dis- persal in Higher Plants. Berlin: Springer. 162 pp. 2nd ed.

170. Wheelwright NT, Orians GH. 1982. Seed dispersal by animals: contrasts with pollen dispersal, problems of terminology, and constraints on coevolution. Am. Nat. 119:402-13

171. Willson MF. 1986. Avian frugivory and seed dispersal in eastern North America. Curr. Ormithol. 3:223-79

172. Willson MF. 1993. Mammals as seeddispersal mutualists in North America. Oikos 67:159-76

173. Zamora R. 1990. The fruit diet of Ringouzels (Turdus torquatus) wintering in the Sierra Nevada (south-east Spain). Alauda 58:67-70 